\title{
Uspešno usklajevanje dvojne kariere vrhunskih športnikov
}

\author{
Mojca Braz* \\ Fakulteta za komercialne in poslovne vede, Lava 7, 3000 Celje, Slovenija \\ braz.mm@gmail.com \\ Mateja Gorenc \\ Mednarodna fakulteta za družbene in poslovne študije, Mariborska 7, 3000 Celje, Slovenija \\ mateja.gorenc@gmail.com
}

\begin{abstract}
Povzetek:
Raziskovalno vprašanje (RV): Kateri dejavniki vplivajo na uspešno usklajevanje dvojne kariere vrhunskih športnikov?

Namen: Namen uspešnega usklajevanja dvojne kariere vrhunskih športnikov je pridobitev izobrazbe med samo športno kariero. Pridobljena izobrazba pripomore k večji zaposljivosti športnika po končani športni karieri.

Metoda: Uporabili smo kvantitativno metodo v raziskovanju, deskriptivno analizo, linearno in multiplo analizo. Statistično analizo smo izvedli s statističnem programom SPSS.

Rezultati: Iz raziskave smo ugotovili, da na uspešno usklajevanje dvojne kariere vplivajo osebnostni dejavniki in značilnosti študijskega programa.

Organizacija: Višje oziroma visokošolski zavodi se morajo zavedati, da morajo prilagoditi študij športnikom, saj se bo s tem povečala izobrazba športnikov.

Družba: Športniki bodo po končani športni karieri z izobrazbo lažje zaposljivi.

Originalnost: Iz pridobljenih podatkov in ugotovitev so oblikovani predlogi za izboljšanje možnosti dvojnih karier športnikov v Sloveniji.

Omejitve/nadaljnje raziskovanje: V raziskavi smo se omejili, da smo anketirali Slovenske vrhunske športnike.
\end{abstract}

Ključne besede: dvojna kariera športnikov, kariera $v$ športu, študent športnik, odločitev za študij, uspeh pri študiju, status študenta, študij na daljavo, evalvacija prilagoditev študija športnikom.

\section{Uvod}

Pojem dvojne kariere je mišljen kot uspešno usklajevanje športne in akademske kariere vrhunskih amaterskih športnikov. K uspešnemu izvajanju dvojne kariere športnikov poleg izobraževanja, zaposlovanja, zdravstva, sociale in financ prispevajo tudi starši, trenerji, športni centri, športne organizacije in športna združenja.

Strokovna skupina EU za izobraževanje in usposabljanje v športu, ki šteje sedemindvajset strokovnjakov (med njimi pa ni bilo predstavnika Slovenije), je septembra 2012 odobrila smernice EU za dvojno kariero športnikov. Objavljene so v dokumentu »EU Guidelines on Dual Careers of Athletes«. Ta dokument je kot evropska spodbuda usklajevanju karier 
rezultat projekta Regional Centre for Dual Career Politics and Advocacy - DC4AC, ki ga financira program EU Erasmus +.

Smernice so v prvi vrsti namenjene oblikovalcem politik v državah članicah EU kot vodilo za implementiranje akcijsko usmerjenih nacionalnih smernic za dvig ozaveščenosti o dvojni karieri športnikov, saj temeljijo na relevantnih teorijah, raziskavah in praktičnih izkušnjah, glede dvojne kariere v državah članicah. Ključna pri strategiji sta pravni in finančni okvir, zelo pomembne pa so tudi prilagoditve izobraževanja. Smernice naj bi prispevale k izmenjavi dobrih praks med državami članicami EU.

Številni perspektivni športniki ravno v času, ko bi lahko dosegli najbolj odmevne rezultate, končajo športno kariero, saj ne morejo uskladiti študijskih obveznosti z zahtevami športa. Vrhunska športna kariera je $v$ današnjem času do zadnje malenkosti voden proces, $v$ katerem deluje vrsta strokovnjakov, ki stremijo zgolj za vrhunskimi dosežki. Pri tem pa se moramo zavedati, da športniki amaterji kljub doseganju elitnih rezultatov za svoje dosežke ne morejo (ne smejo) biti materialno nagrajeni, saj s tem avtomatično prestopijo v profesionalne vode.

Prednost dvojne kariere je pridobitev izobrazbe med samo športno kariero ali kmalu po zaključku le-te, kar pripomore $\mathrm{k}$ večji zaposljivosti športnika, zmanjšanju stresa in eksistenčnih problemov po končani športni karieri.

V Sloveniji kljub obsežni zakonodaji, ki ureja šolstvo in šport nimamo izdelanega sistema, s katerim bi enotno pomagali vrhunskim športnikom pri odločitvi za dvojno kariero, ter določili statusne pravice, ki bi jim omogočale uskladitev šolanja in nadaljnje športne kariere. Cilj raziskave je ugotoviti kateri dejavniki vplivajo na uspešno usklajevanje dvojne kariere.

\section{Teoretična izhodišča}

Različni avtorji (Brečko, Holland, Možina, Roe, Super, Stein ), opisujejo dejavnike uspešne poklicne kariere. V procesu odločanja za poklic oziroma študij, so med najpomembnejšimi posameznikove osebnostne lastnosti (sposobnosti in spretnosti, temperament, značaj, želje, interesi, preference, vrednote in motivacija), telesne značilnosti in s tem povezano zdravje, ter učne-delovne navade.

Dejavniki uspešne kariere (napredovanja) so po psiholoških teorijah (Konrad, 1996) poklicni interes, sposobnosti, kompetence, znanja, spretnosti, dinamika, povezana z življenjskim razvojem in motivacijo; medtem ko sociološke teorije poudarjajo položaj posameznika $v$ družbi (socialno ekonomski status, poklic staršev, vpliv šole). Med dejavniki razvoja uspešne poklicne kariere so dejavniki v okolju (normativna ureditev, trg delovne sile, dejavniki dejavnosti), pri posamezniku (spol, starost, stopnja pridobljene formalne izobrazbe, delovne izkušnje, izobraževanje, delovna doba) in dejavniki na nivoju organizacije (organizacijska struktura, gospodarjenje, poslovna uspešnost in razvojne strategije organizacije, obstoječa kadrovska struktura, delovne okoliščine, delovna uspešnost posameznika ter sistem 
ocenjevanja delovne uspešnosti in zadovoljstvo $\mathrm{z}$ delom oziroma izobraževanje, ocenjevanje delovne uspešnosti (Ferjan 2003, 470).

Na uspešno dvojno oziroma poklicno kariero športnikov pa vplivajo še dejavniki povezani s športom. Povezavo med uspehom v športu in pri študiju so raziskali že Coakleya (1990; v Sivec, 2005); Marsh (1993; v Sivec, 2005); Ogilvie in Howe,1982, 1986; v Cecić Erpič, 2002a, in ugotovili, ali vrhunski uspehi v športu negativno vplivajo na študij športnikov ali da športna kariera pozitivno vpliva na izobraževanje športnikov. Raziskave o statusu športnika, ki so jih naredili Kovač in sodelavci, 1998; Sivec, 2005; Jurak, Kovač in Strel, 2005, kažejo, da »Status « učenca/dijaka/študenta športnika in možne prilagoditve študija ter možnost študija na daljavo pozitivno vplivajo na uspešnost pri študiju. Gaston-Gayles (2002); Pettaway Willis (2005); Vroom, (1964); Adler in Adler (1991) ter Clow (2000) so preverjali akademsko, športno in karierno motivacijo športnikov in ugotovili, da obstaja povezava med motivacijo in študijem ter športom.

Z namenom, da bi ugotovili kateri dejavniki vplivajo na uspešno usklajevanje dvojne kariere smo si zastavili raziskovalno vprašanje:

Na športnikovo izbiro študija vplivajo osebnostni dejavniki, značilnosti študijskega programa in značilnosti športne kariere.

Na podlagi raziskovalnega vprašanja smo zastavili tri hipoteze:

H1: Na športnikovo izbiro študija vplivajo osebnostni dejavniki (sposobnosti, interesi, predhodni šolski uspeh, motivacija).

H2: Na športnikovo izbiro študija vplivajo značilnosti študijskega programa (zahtevnost, obseg študijskih obremenitev, možne prilagoditve).

H3: Na športnikovo izbiro študija vplivajo tudi značilnosti športne aktivnosti (obseg treningov, tekmovanj, odsotnosti, fizična zahtevnost športa, oddaljenost bivanja od objektov za trening, nivo tekmovanja, motiviranost za šport, uspeh pri športu).

\section{Metode}

Za zbiranje podatkov smo uporabili kvantitativno metodo. Standardizirano spletno anketo smo pripravili in izvedli v letu 2017, trajala pa je do leta 2019, saj je bilo za njeno izvedbo treba zagotoviti vso ustrezno informacijsko podporo. Pred dejanskim začetkom anketiranja je bilo izvedeno pilotsko izvajanje vprašalnika na Olimpijskem komiteju Slovenije in na Fakulteti za komercialne in poslovne vede v Celju. Anketa pred tem še ni bila uporabljena. Anketni vprašalnik smo poslali več kot 400 športnikom v Sloveniji, od katerih pa smo dobili ustreznih za potrebe raziskave le 112. Segment anketirancev smo izbrali v klubu olimpijcev, ki so imeli v aktivnih letih kariero vrhunskih športnikov, med katero so se ali pa se niso 
odločili še za akademsko kariero. Spletno anketo smo izvajali v obdobju od 1. 7. 2017 do 23. 10. 2019. Anketo smo uspešno izvedli in je bila 23. 10. 2019 tudi zaključena.

Hipoteze smo preverili na osnovi anketiranja športnikov, ki so usklajevali dvojno kariero. Za analizo dobljenih podatkov smo uporabili linearno multiplo regresijsko analizo (metodo Enter, zato da smo vse izbrane spremenljivke hkrati vključili v model. Metoda enter nam v rezultatih prikaže vse spremenljivke, četudi njihov vpliv ni statistično pomemben). Od vsakega dejavnika smo dobili povprečno vrednost odgovora, ki smo jo obdelali s Pearsonovim koeficientom korelacije in regresijsko analizo. Uspešnost smo merili z Likertovo lestvico od 1 do 5.

\section{Rezultati}

$\mathrm{V}$ tem poglavju prikazujemo rezultate kvantitativne raziskave (Anketni vprašalnik). $\mathrm{Ob}$ preverjanju hipotez prikazujemo operacionalizacijo spremenljivk in strukturo merilnega instrumenta (spletnega anketnega vprašalnika). V sklopu statistične analize prikazujemo opisno statistiko in rezultate hipotez.

Za namen raziskave smo kot vzorec postavili vrhunske športnike, ki so se v času svoje športne kariere odločili za študij oziroma usklajevanje dvojne kariere. V kvantitativni raziskavi je sodelovalo 396 anketirancev, od katerih se jih je na izpolnitev ankete odzvalo 165, od teh pa je bilo veljavnih 112 vprašalnikov. Izločili smo 53 vprašalnikov, saj niso bili izpolnjeni v celoti. Vzorec kvantitativne raziskave je $\mathrm{N}=112$, ki ga predstavljajo športniki v Republiki Sloveniji, stari od 19 do 76 let. Na sliki 1 so prikazani demografski podatki anketirancev.
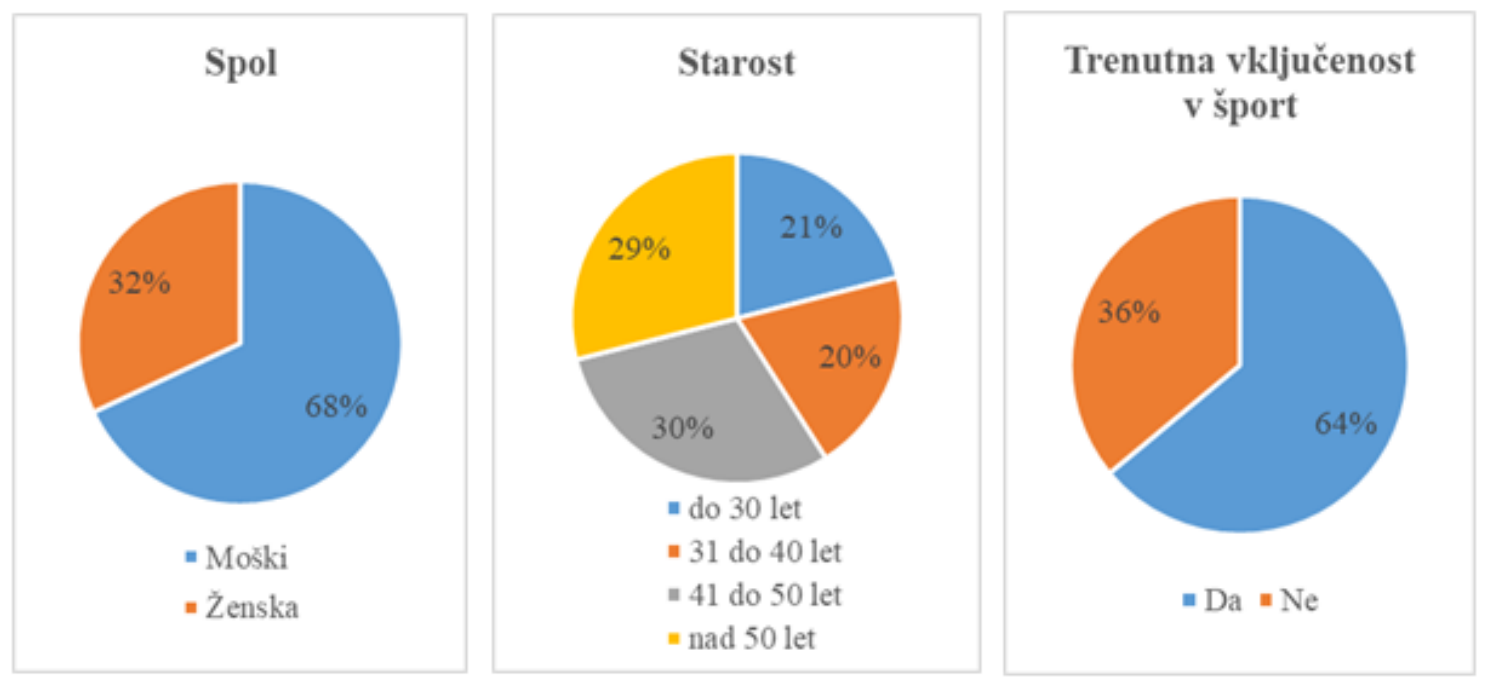

Slika 1. Demografski podatki 


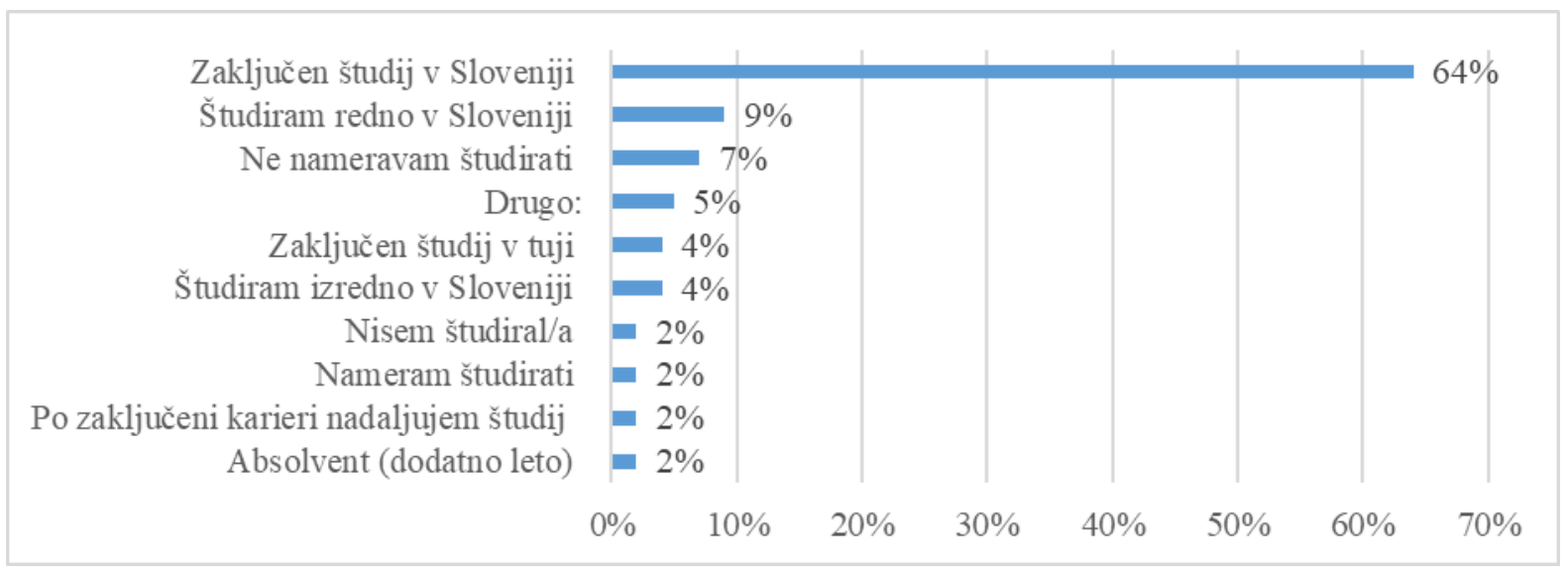

Slika 2. Trenutna vključenost v študij

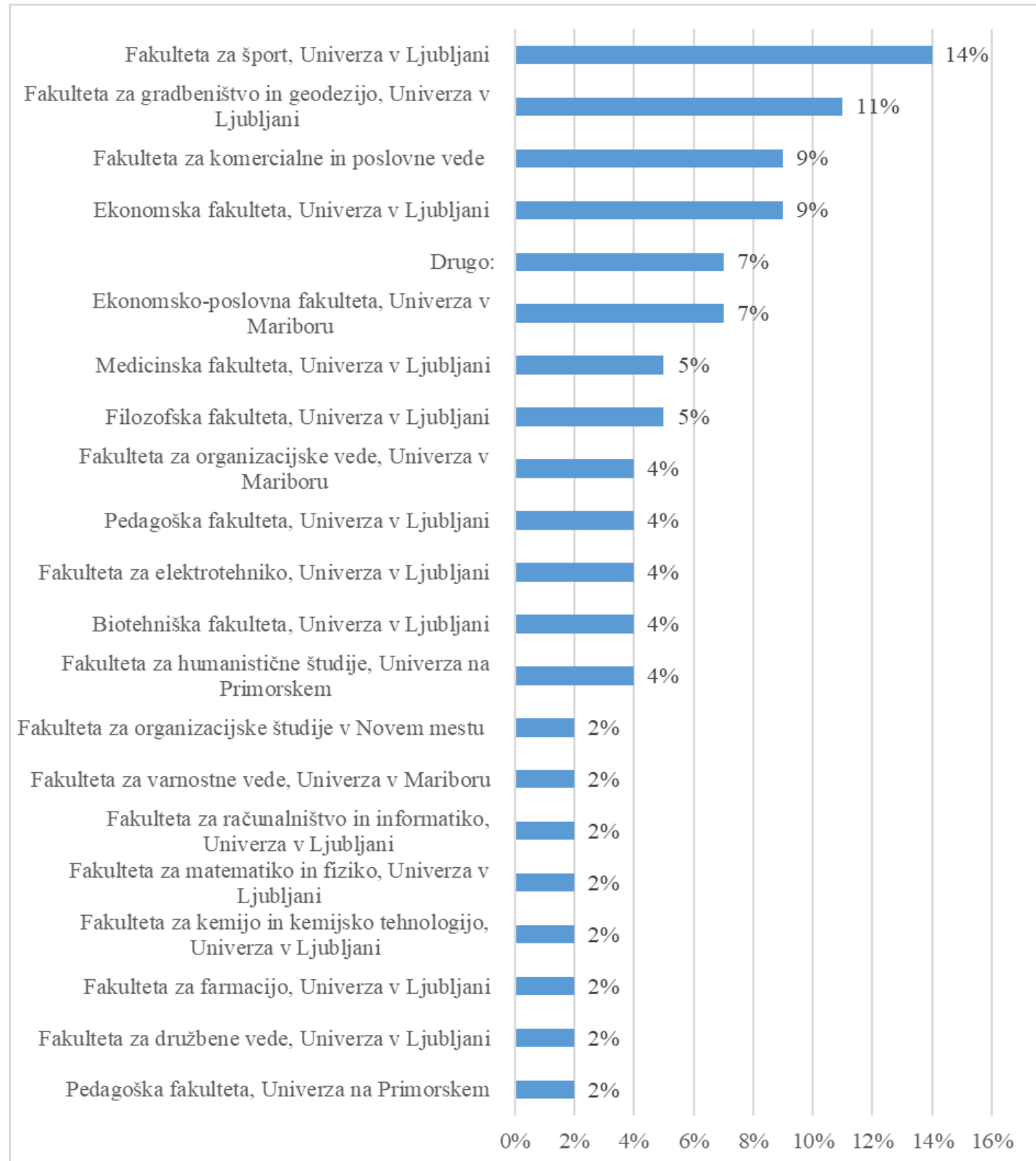

Slika 3. Ime izobraževalnega zavoda, kjer ste se šolali (se šolate) 
Izzivi prihodnosti / Challenges of the Future,

Avgust / August 2020, leto / year 5, številka / number 3, str. / pp. 151-173.

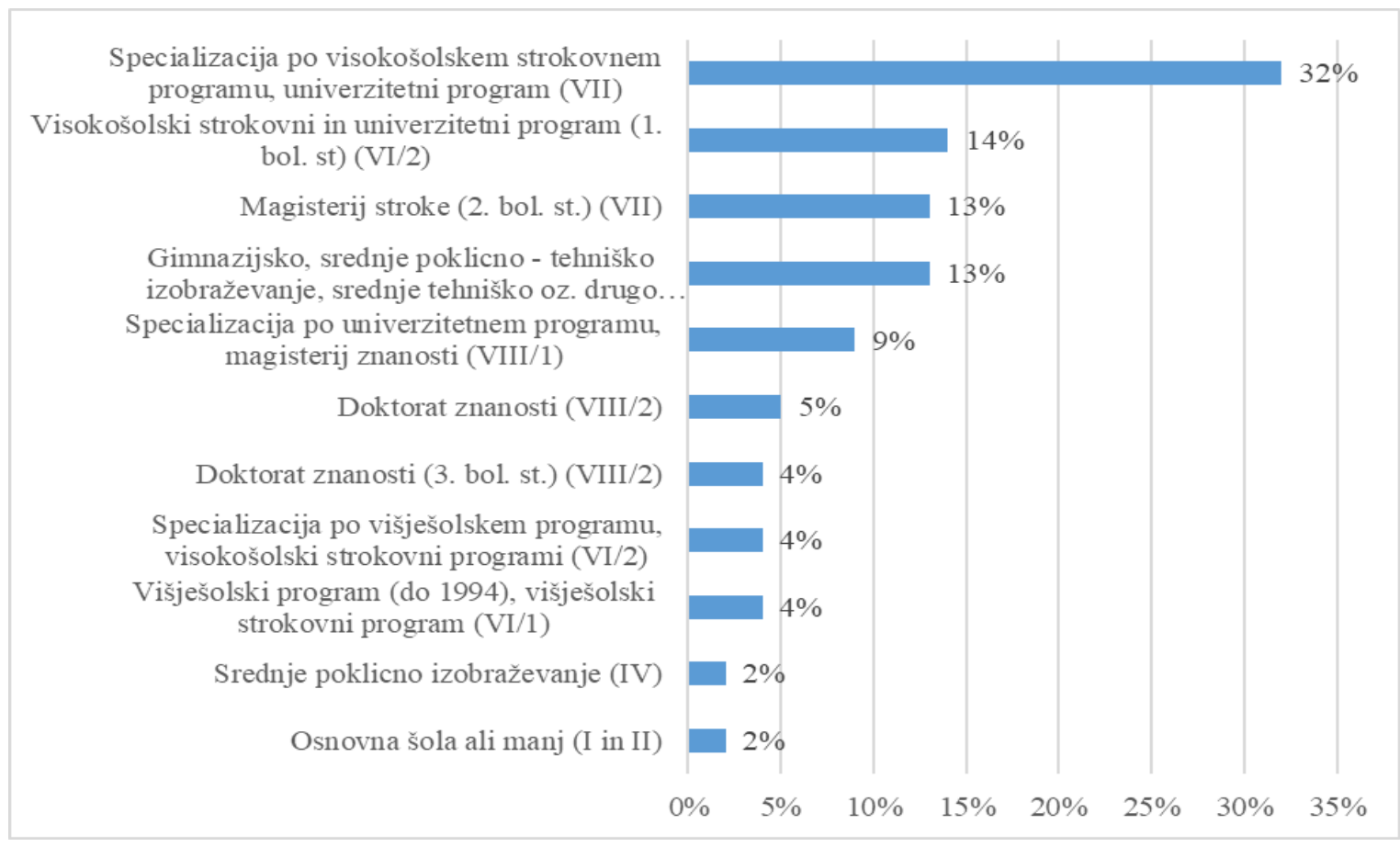

Slika 4. Zaključena stopnja izobrazbe

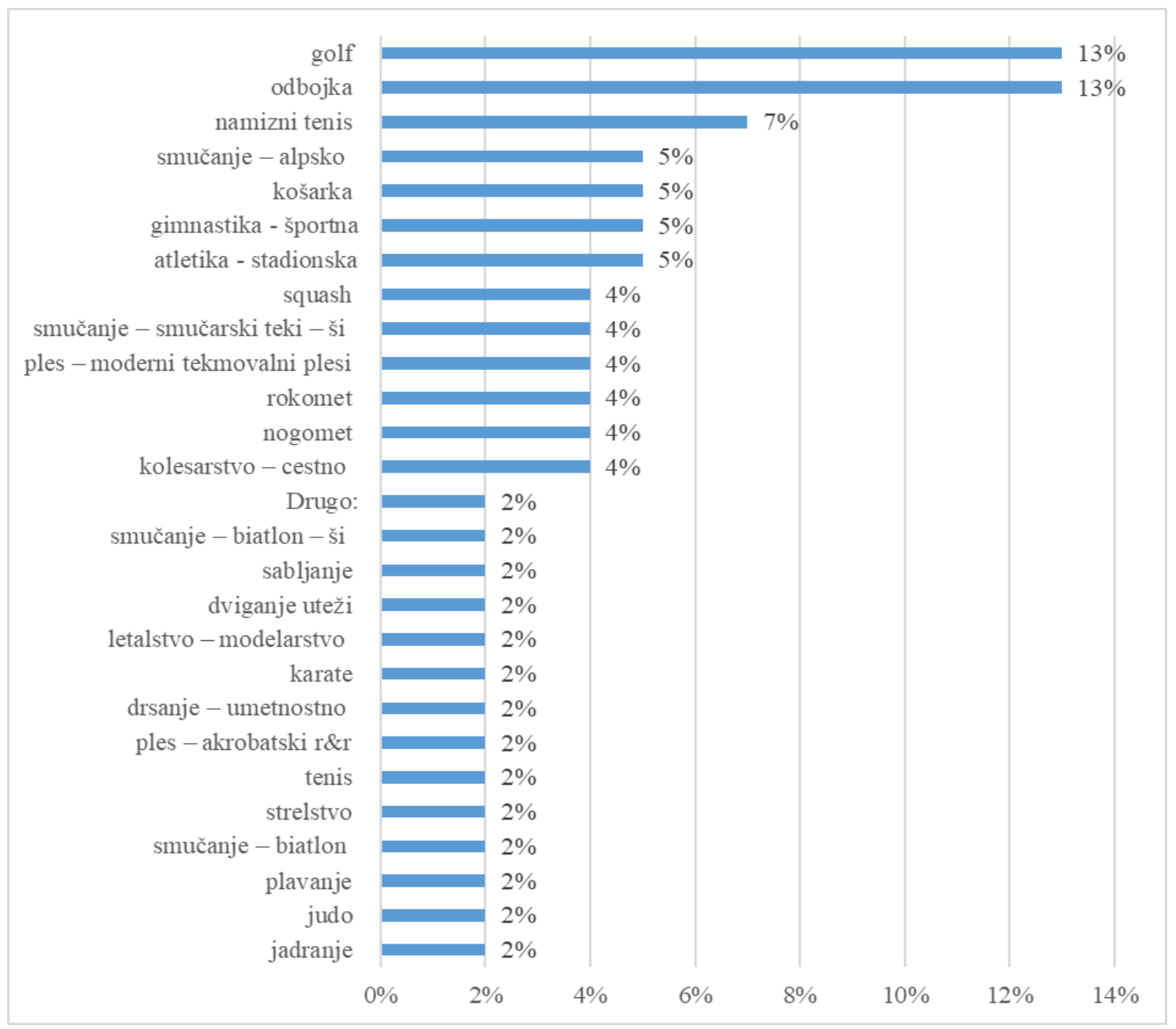

Slika 5. Športna panoga 


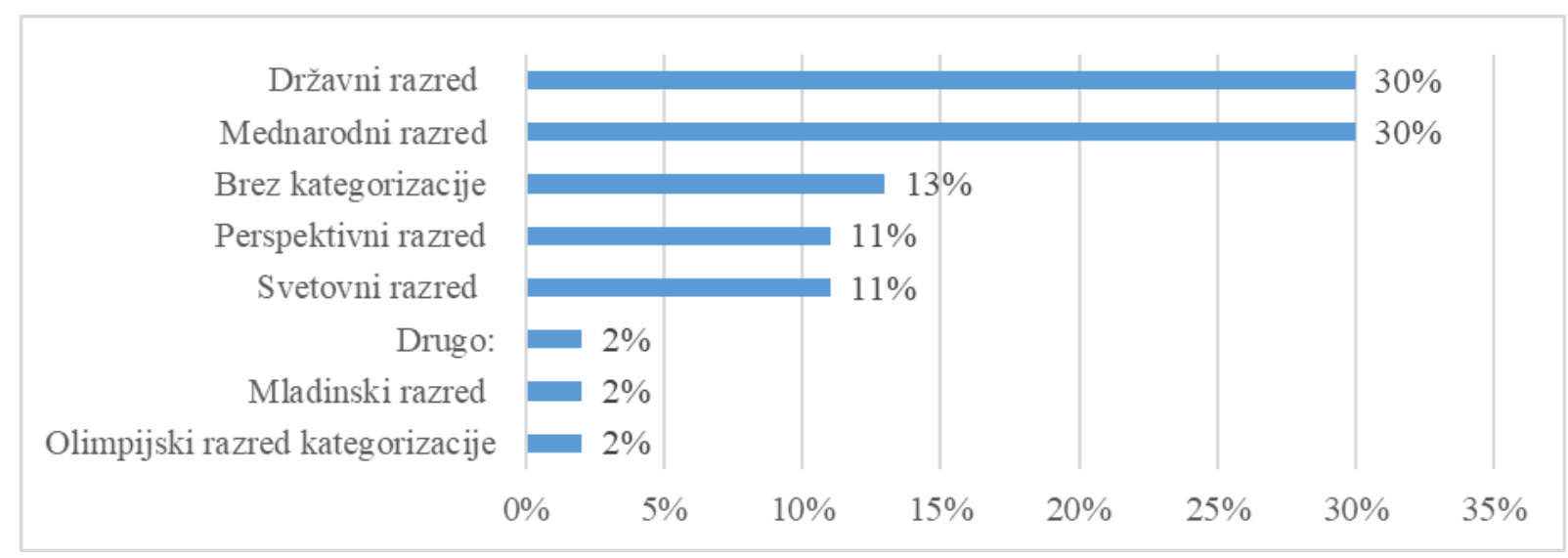

Slika 6. Kategorizacija glede na OKS

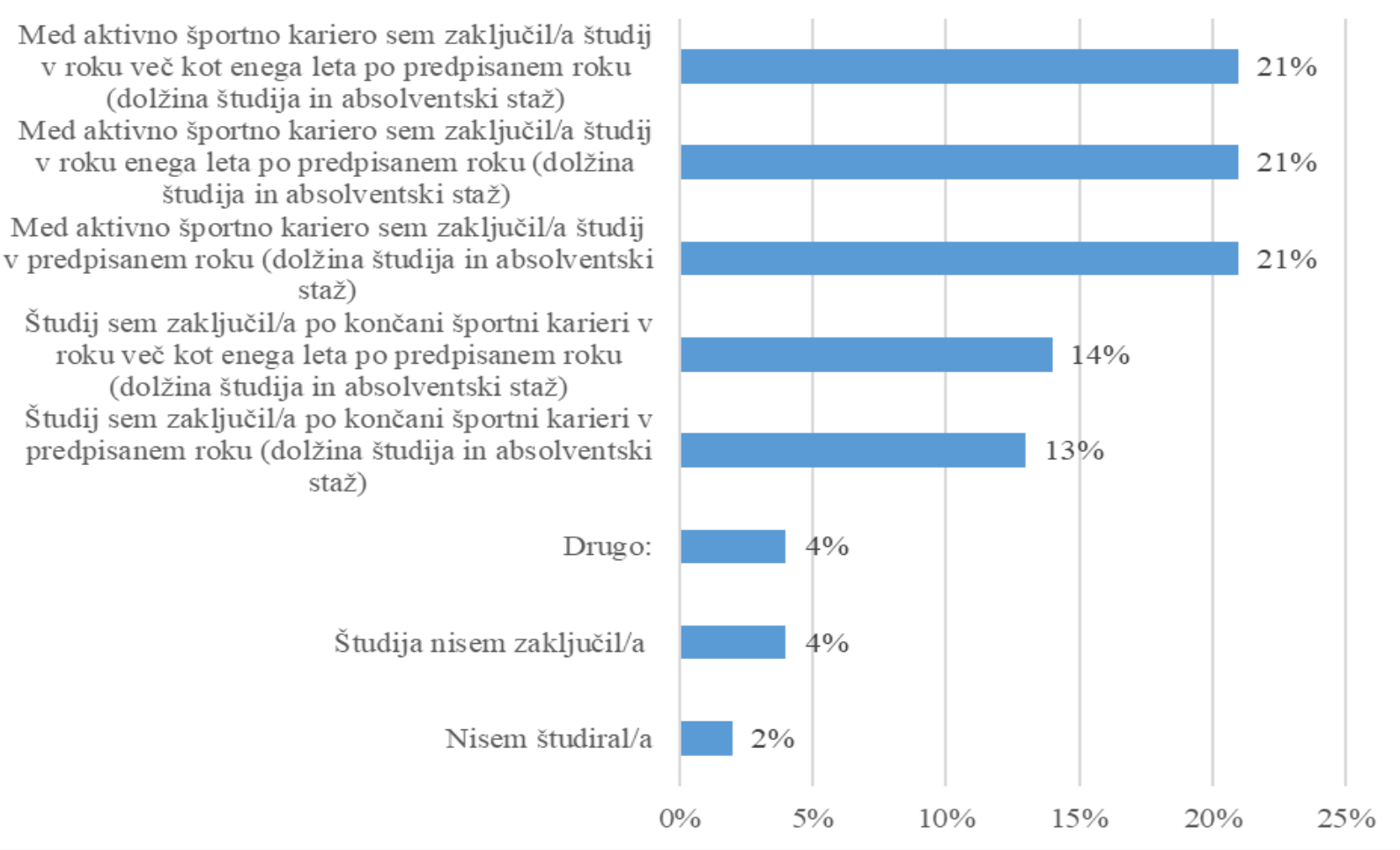

Slika 7. Usklajevanje športa in študija

\subsection{Opisna statistika}

Ključne značilnosti podatkov so izražene s pomočjo metod opisne statistike. Standardni odklon pove, kako so podatki razpršeni okoli aritmetične sredine. Visoka vrednost standardnega odklona pomeni, da so vrednosti bolj razpršene, nizka pa, da so bolj zgoščene okoli aritmetične sredine. Trditve, ki opisujejo spremenljivke so predstavljene v tabelah od Tabela 1 do Tabela 4 . Vse trditve so bile ocenjene na lestvici od 1 do 5 , pri čemer za izbrano oceno 1 pomeni »Zelo nepomembno« za izbrano trditev ocena 2 pomeni »Ni pomembno« za izbrano trditev ocena 3 pomeni »Niti pomembno, niti nepomembno« za izbrano trditev ocena 4 pomeni »Pomembno« za izbrano trditev ocena 5 pa pomeni »Zelo pomembno«. 
Tabela 1. Dejavniki izbire študija

\begin{tabular}{|c|c|c|c|c|c|}
\hline $\begin{array}{l}\text { DEJAVNIKI IZBIRE ŠTUDIJA - Uspešno } \\
\text { usklajevanje dvojne kariere }\end{array}$ & $\mathbf{N}$ & Minimum & Maximum & Povprečje & $\begin{array}{r}\text { Standardni } \\
\text { odklon }\end{array}$ \\
\hline Bližina kraja študija kraju treningov & 110 & 1 & 5 & 4,40 & 0,969 \\
\hline 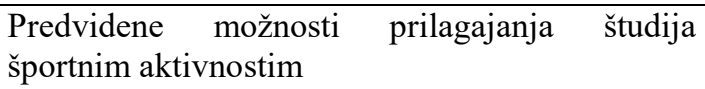 & 110 & 1 & 5 & 4,31 & 0,916 \\
\hline $\begin{array}{l}\text { Interes oziroma veselje do posamezne smeri } \\
\text { sttudija }\end{array}$ & 110 & 1 & 5 & 4,16 & 0,914 \\
\hline Možnost za treninge v kraju, kjer se izvaja študij & 110 & 1 & 5 & 4,31 & 0,993 \\
\hline Štipendija izobraževalne institucije & 110 & 1 & 5 & 3,62 & 1,125 \\
\hline $\begin{array}{l}\text { Dobri pogoji za ukvarjanje s športom v okviru } \\
\text { fakultete oz. višje/visoke šole }\end{array}$ & 110 & 1 & 5 & 3,75 & 1,215 \\
\hline $\begin{array}{l}\text { Razumevanje izobraževalne organizacije za moje } \\
\text { športno udejstvovanje in podpora pri } \\
\text { izobraževanju. }\end{array}$ & 110 & 2 & 5 & 4,45 & 0,737 \\
\hline Drugo & 2 & 5 & 5 & 5,00 & 0,000 \\
\hline
\end{tabular}

Tabela 2. Osebnostni dejavniki

\begin{tabular}{|c|c|c|c|c|c|}
\hline $\begin{array}{l}\text { OSEBNOSTNI DEJAVNIKI - } \\
\text { Uspešno usklajevanje dvojne kariere }\end{array}$ & $\mathbf{N}$ & Minimum & Maximum & Povprečje & $\begin{array}{r}\text { Standardni } \\
\text { odklon }\end{array}$ \\
\hline Intelektualne sposobnosti & 110 & 1 & 5 & 4,36 & 0,775 \\
\hline Športne sposobnosti & 110 & 1 & 5 & 3,91 & 0,982 \\
\hline Emocionalna inteligentnost & 110 & 1 & 5 & 4,15 & 1,057 \\
\hline Medosebna oz. socialna inteligentnost & 110 & 1 & 5 & 4,02 & 0,824 \\
\hline Interes za šport & 110 & 2 & 5 & 4,20 & 0,907 \\
\hline Interes za študij & 110 & 3 & 5 & 4,36 & 0,646 \\
\hline Interes za uspešno poklicno kariero & 110 & 3 & 5 & 4,09 & 0,749 \\
\hline Predhodni šolski uspeh & 110 & 1 & 5 & 3,31 & 1,047 \\
\hline Motiviranost za šport & 110 & 1 & 5 & 4,15 & 0,907 \\
\hline Motiviranost za študij & 110 & 1 & 5 & 4,25 & 0,795 \\
\hline Motiviranost za poklicni uspeh & 110 & 1 & 5 & 3,75 & 0,999 \\
\hline Organizacijske sposobnosti & 110 & 1 & 5 & 4,58 & 0,759 \\
\hline Znotraj-osebna inteligentnost & 110 & 2 & 5 & 4,18 & 0,815 \\
\hline Delavnost & 110 & 2 & 5 & 4,62 & 0,704 \\
\hline Vztrajnost & 110 & 2 & 5 & 4,65 & 0,696 \\
\hline $\begin{array}{l}\text { Ekstravertiranost (interes za družabne dogodke, } \\
\text { aktivni, energični. }\end{array}$ & 110 & 1 & 5 & 3,15 & 0,887 \\
\hline Introvertiranost (usmerjenost vase) & 110 & 1 & 5 & 3,05 & 1,003 \\
\hline Čustvena stabilnost & 110 & 1 & 5 & 4,29 & 0,828 \\
\hline Težnja po uveljavljanju lastnega mnenja & 110 & 1 & 5 & 3,13 & 1,134 \\
\hline $\begin{array}{l}\text { Sprejemljivost (ohranjanje pozitivnih odnosov } \mathrm{z} \\
\text { drugimi; sposobnost razumevanja z drugimi } \\
\text { osebami, premagovanje frustracij, ki so povezane z } \\
\text { življenjem v skupini) }\end{array}$ & 110 & 1 & 5 & 3,87 & 1,015 \\
\hline $\begin{array}{l}\text { Odprtost - kulturna sofisticiranost in odprtost za } \\
\text { nove izkušnje }\end{array}$ & 110 & 1 & 5 & 3,67 & 0,978 \\
\hline Znanje (povezano s študijskimi vsebinami) & 110 & 1 & 5 & 3,67 & 0,940 \\
\hline Uporaba nedovoljenih pripomočkov & 110 & 1 & 5 & 2,00 & 1,241 \\
\hline
\end{tabular}


»nadaljevanje«

\begin{tabular}{llllll} 
Sreča & 110 & 1 & 5 & 3,18 & 1,396 \\
\hline Izpitne spretnosti & 110 & 1 & 5 & 3,36 & 1,002 \\
\hline Izpitna bojazen, stres & 110 & 1 & 5 & 2,84 & 1,080 \\
\hline Timsko delo, uspešno sodelovanje s sošolci & 110 & 1 & 5 & 3,85 & 1,091 \\
\hline Dobro organiziran čas & 110 & 3 & 5 & 4,76 & 0,506 \\
\hline $\begin{array}{l}\text { Organizirano učenje, upoštevanje pravilnih metod } \\
\text { ter smotrna priprava na izpit }\end{array}$ & 110 & 2 & 5 & 4,27 & 0,777 \\
\hline Dobre učne navade & 110 & 1 & 5 & 4,29 & 0,892 \\
\hline Dobre delovne navade & 110 & 3 & 5 & 4,69 & 0,602 \\
\hline Drugo & 4 & 3 & 5 & 4,00 & 1,155 \\
\hline
\end{tabular}

Tabela 3. Značilnosti študijskega programa

\begin{tabular}{lrrrrr}
\hline $\begin{array}{l}\text { ZNAČILNOSTI ŠTUDIJSKEGA } \\
\text { PROGRAMA - } \\
\text { Uspešno usklajevanje dvojne kariere }\end{array}$ & N & Minimum & Maximum & Povprečje & $\begin{array}{r}\text { Standardni } \\
\text { odklon }\end{array}$ \\
\hline Zahtevnost študijskega programa & 110 & 2 & 5 & 4,35 & 0,747 \\
\hline Obseg vseh študijskih obremenitev & 110 & 2 & 5 & 4,25 & 0,771 \\
\hline Obseg obveznih študijskih vsebin & 110 & 2 & 5 & 4,31 & 0,714 \\
\hline Možnosti prilagoditve študijskih obveznosti & 110 & 3 & 5 & 4,69 & 0,602 \\
\hline Fleksibilnost višje/visokošolskega zavoda & 110 & 3 & 5 & 4,56 & 0,657 \\
\hline Drugo & 4 & 3 & 5 & 4,00 & 1,155 \\
\hline
\end{tabular}

Tabela 4. Značilnosti športne aktivnosti

\begin{tabular}{|c|c|c|c|c|c|}
\hline $\begin{array}{l}\text { ZNAČILNOSTI ŠPORTNE AKTIVNOSTI - } \\
\text { Uspešno usklajevanje dvojne kariere }\end{array}$ & $\mathbf{N}$ & Minimum & Maximum & Povprečje & $\begin{array}{r}\begin{array}{r}\text { Standardni } \\
\text { odklon }\end{array} \\
\end{array}$ \\
\hline Obseg treningov & 110 & 2 & 5 & 4,29 & 0,782 \\
\hline Število tekmovanj (tekmovalnih dni letno) & 110 & 2 & 5 & 4,24 & 0,789 \\
\hline Število dni odsotnosti od študijskih obveznosti & 110 & 2 & 5 & 4,00 & 0,857 \\
\hline Fizična zahtevnost športa & 110 & 2 & 5 & 3,89 & 0,871 \\
\hline Oddaljenost bivanja od objektov za trening & 110 & 1 & 5 & 4,11 & 0,871 \\
\hline Nivo tekmovanj & 110 & 2 & 5 & 3,89 & 0,892 \\
\hline Število dni priprav letno & 110 & 3 & 5 & 4,04 & 0,716 \\
\hline Čas, porabljen za fizioterapijo & 110 & 1 & & 3,09 & 1,019 \\
\hline $\begin{array}{l}\text { Čas, porabljen za regeneracijo (poleg nočnega } \\
\text { počitka) }\end{array}$ & 110 & 1 & & 3,60 & 1,127 \\
\hline $\begin{array}{l}\text { Čas, porabljen za individualno psihološko } \\
\text { pripravo }\end{array}$ & 110 & 2 & & 3,55 & 0,874 \\
\hline Čas, porabljen za delo s športnim psihologom & 110 & 1 & & 3,11 & 1,026 \\
\hline
\end{tabular}

\subsection{Multivariantna analiza}

$\mathrm{V}$ nadaljevanju predstavljamo multivariantne analize povezav med proučevanim spremenljivkami. Osnova za razumevanje medsebojnih vplivov med spremenljivkami in prvi ključni pogoj za izvajanje linearne regresijske analize je ugotavljanje medsebojne povezanosti med pari neodvisnih spremenljivk ter med neodvisnimi in odvisnimi spremenljivkami. V 
tabelah prikazujemo povzetek regresijske analize (vrednosti korelacijskih koeficientov, vrednosti determinacijskih oziroma prilagojenih determinacijskih koeficientov), $F$-testa (ANOVA) s pomočjo katerih smo preverili hipoteze. Na podlagi dobljenih rezultatov smo hipoteze potrdili ali zavrgli.

Prva hipoteza se glasi:

H1: Na športnikovo izbiro študija vplivajo osebnostni dejavniki (sposobnosti, interesi, predhodni šolski uspeh, motivacija).

Za testiranje prve hipoteze H1 preverimo povezanost med spremenljivkama Izbira študija dvojna kariera (izbira_st_l) in Osebnostni dejavniki - dvojna kariera (oseb_dej_l). Povezanost med tema dvema spremenljivkama preverimo $\mathrm{z}$ naslednjim populacijskim regresijskim modelom in hipotezo.

Populacijski regresijski model:

$i z b i r a \_s t \_1=\beta_{1}+\beta_{2} * o s e b \_d e j \_1+u$

Hipoteza:

$H_{0}: \beta_{2}=0$

$H_{1}: \beta_{2} \neq 0$

Hipotezo H1 smo testirali z linearno regresijsko analizo (metoda Enter), kjer je odvisna spremenljivka Izbira študija - dvojna kariera (izbira_st_1) in neodvisna spremenljivka Osebnostni dejavniki - dvojna kariera (oseb_dej_l).

Tabela 5. Linearna regresija $-\mathrm{H} 1$

\section{Povzetek modela}

\begin{tabular}{|c|c|}
\hline $\mathbf{M}$ & $\mathbf{R}$ \\
\hline
\end{tabular}

\begin{tabular}{lllll}
\hline 1 & $0,276^{\mathrm{a}}$ & 0,076 & 0,068 & 0,56672
\end{tabular}

a. Neodvisne spremenljivke: Osebnostni dejavniki - dvojna kariera ANOVA $^{a}$ 


\begin{tabular}{lllllll} 
Model & & $\begin{array}{l}\text { Vsota } \\
\text { kvadratov }\end{array}$ & sp & $\begin{array}{l}\text { Povprečni } \\
\text { kvadrat }\end{array}$ & F & p-vrednost \\
\hline 1 & Regresija & 2,864 & 1 & 2,864 & 8,918 &, $003^{\mathrm{b}}$ \\
& & & & & \\
& Preostali & 34,687 & 108 & 0,321 & & \\
& & & & & & \\
& Skupaj & 37,551 & 109 & & & \\
\end{tabular}

a. Odvisna spremenljivka: Izbira študija - dvojna kariera

b. Neodvisne spremenljivke: Osebnostni dejavniki - dvojna kariera

Koeficienti $^{\text {a }}$

Stand.

Nestand. koeficienti koeficienti

\begin{tabular}{|c|c|c|c|c|c|c|}
\hline \multirow[b]{2}{*}{ Model } & & & \multirow[b]{2}{*}{$\mathbf{t}$} & \multirow[b]{2}{*}{ p - vrednost } \\
\hline & & $\boldsymbol{\beta}$ & $\begin{array}{l}\text { St. } \\
\text { napaka }\end{array}$ & Beta & & \\
\hline \multirow[t]{2}{*}{1} & (Konstanta) & 2,694 & 0,488 & & 5,519 & 0,000 \\
\hline & $\begin{array}{l}\text { Osebnostni dejavniki } \\
\text { - dvojna kariera }\end{array}$ & 0,372 & 0,125 & 0,276 & 2,986 & 0,003 \\
\hline
\end{tabular}

a. Odvisna spremenljivka: Izbira študija - dvojna kariera

$\mathrm{V}$ tabeli 5 multipli korelacijski koeficient $R$ kaže jakost povezanosti med odvisno spremenljivko Izbira študija - dvojna kariera (izbira_st_1) in neodvisno spremenljivko Osebnostni dejavniki - dvojna kariera (oseb_dej_l). Multipli korelacijski koeficient $R$ znaša 0,276, kar kaže na nizko povezanost. Multipli determinacijski koeficient pojasnjuje, da je 6,8 $\%$ celotne variance uspelo pojasniti z vplivom neodvisne spremenljivke, kar predstavlja 93,2 $\%$ nepojasnjenega vpliva. Na podlagi dobljenih rezultatov in vrednosti regresijskih koeficientov $\beta$ lahko hipotezo H1 potrdimo in zaključimo, da na odvisno spremenljivko Izbira študija - dvojna kariera vpliva Osebnostni dejavniki - dvojna kariera. 


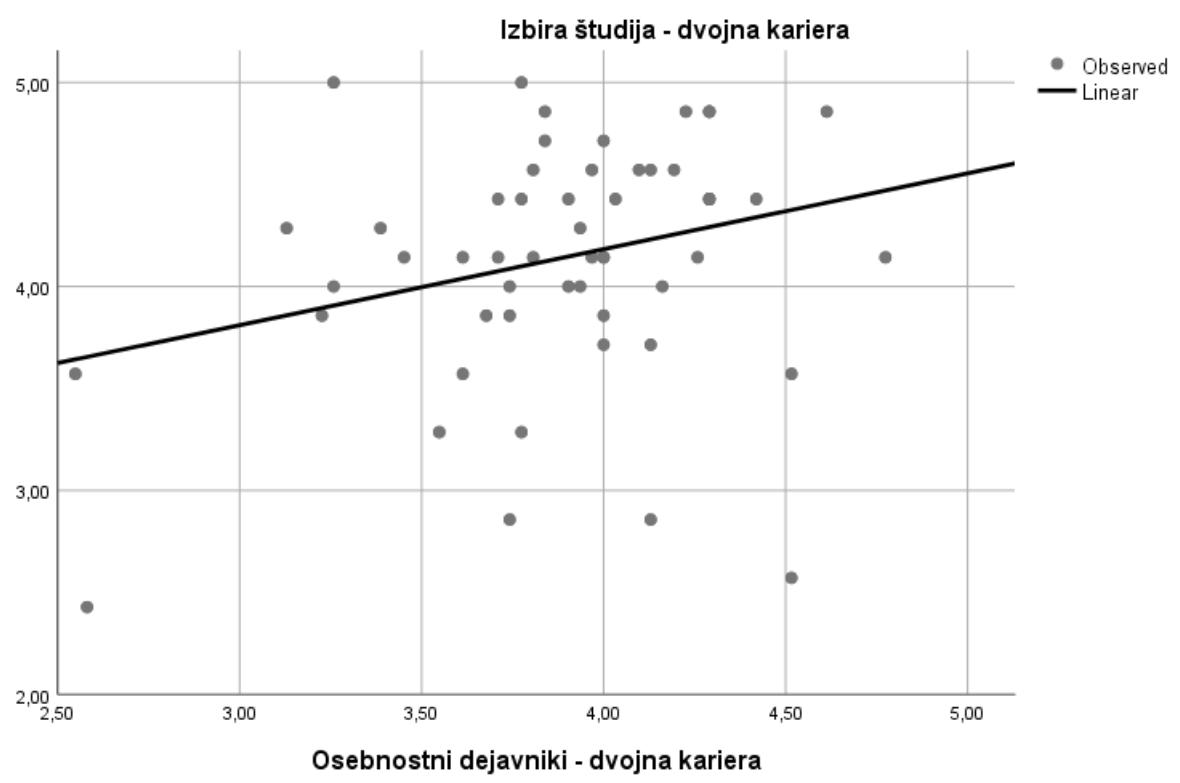

Slika 8. Linearna povezanost odvisne spremenljivke Izbira študija - dvojna kariera in neodvisne spremenljivke Osebnostni dejavniki - dvojna kariera

Slika 8 prikazuje linearno povezanost med odvisno spremenljivko Izbira študija - dvojna kariera in neodvisno spremenljivko Osebnostni dejavniki - dvojna kariera. Vidimo, da gre za pozitivno in linearno povezanost odvisne spremenljivke Izbira študija - dvojna kariera in neodvisne spremenljivke Osebnostni dejavniki-dvojna kariera.

Druga hipoteza se glasi:

H2: Na športnikovo izbiro študija vplivajo značilnosti študijskega programa (zahtevnost, obseg študijskih obremenitev, možne prilagoditve).

Za testiranje druge hipoteze $\mathrm{H} 2$ preverimo povezanost med spremenljivkama Izbira študija dvojna kariera (izbira_st_1) in Značilnosti študijskega programa - dvojna kariera (znac_studij_1). Povezanost med tema dvema spremenljivkama preverimo z naslednjim populacijskim regresijskim modelom in hipotezo.

Populacijski regresijski model:

izbira_st_l $=\beta_{1}+\beta_{2} * z n a c \_s t u d i j \_1+u$

Hipoteza:

$H_{0}: \beta_{2}=0$

$H_{1}: \beta_{2} \neq 0$ 
Hipotezo H2 smo testirali z linearno regresijsko analizo (metoda Enter), kjer je odvisna spremenljivka Izbira študija - dvojna kariera (izbira_st_1) in neodvisna spremenljivka Značilnosti študijskega programa - dvojna kariera (znac_studij_l).

Tabela 6. Linearna regresija $-\mathrm{H} 2$

\section{Povzetek modela}

\begin{tabular}{lllll} 
Model & $\mathbf{R}$ & $\mathbf{R}^{2}$ & Prilagojeni $\mathbf{R}^{2}$ & Standardna napaka ocene \\
\hline 1 & $0,273^{\mathrm{a}}$ & 0,074 & 0,066 & 0,56730
\end{tabular}

a. Neodvisne spremenljivke: Značilnosti študijskega programa - dvojna kariera

ANOVA ${ }^{a}$

\begin{tabular}{|c|c|c|c|c|c|c|}
\hline \multicolumn{2}{|c|}{ Model } & \multirow{2}{*}{$\begin{array}{l}\text { Vsota kvadratov } \\
2,794\end{array}$} & \multirow{2}{*}{$\begin{array}{l}\mathbf{s p} \\
1\end{array}$} & \multirow{2}{*}{$\begin{array}{l}\text { Povprečni kvadrat } \\
2,794\end{array}$} & \multirow{2}{*}{$\begin{array}{l}\mathbf{F} \\
8,681\end{array}$} & \multirow{2}{*}{$\begin{array}{l}\mathbf{p} \\
\text { vrednost } \\
0,004^{\mathrm{b}}\end{array}$} \\
\hline 1 & Regresija & & & & & \\
\hline & Preostali & 34,757 & 108 & 0,322 & & \\
\hline & Skupaj & 37,551 & 109 & & & \\
\hline
\end{tabular}

a. Odvisna spremenljivka: Izbira študija - dvojna kariera

b. Neodvisne spremenljivke: Značilnosti študijskega programa - dvojna kariera

Koeficienti $^{\text {a }}$

\begin{tabular}{|c|c|c|c|c|}
\hline \multirow{2}{*}{ Model } & Nestand. koeficienti & \multirow{2}{*}{$\begin{array}{l}\text { Stand. } \\
\text { koeficienti }\end{array}$} & \multirow[b]{2}{*}{$\mathbf{t}$} & \multirow{2}{*}{$\begin{array}{l}\text { p } \\
\text { vrednos }\end{array}$} \\
\hline & St. napaka & & & \\
\hline 1 (Konstanta) & $2,754 \quad 0,475$ & & 5,802 & 0,000 \\
\hline $\begin{array}{l}\text { Značilnosti študijskega } \\
\text { programa - dvojna kariera }\end{array}$ & $0,3130,106$ & 0,273 & 2,946 & 0,004 \\
\hline
\end{tabular}

a. Odvisna spremenljivka: Izbira študija - dvojna kariera

V tabeli 6 multipli korelacijski koeficient $R$ kaže jakost povezanosti med odvisno spremenljivko Izbira študija - dvojna kariera (izbira_st_1) in neodvisno spremenljivko Značilnosti študijskega programa - dvojna kariera (znac_studij_l). Multipli korelacijski koeficient $R$ znaša 0,273, kar kaže na nizko povezanost. Multipli determinacijski koeficient pojasnjuje, da je 6,6 \% celotne variance uspelo pojasniti z vplivom neodvisne spremenljivke, kar predstavlja 93,4 \% nepojasnjenega vpliva. Na podlagi dobljenih rezultatov in vrednosti regresijskih koeficientov $\beta$ lahko hipotezo $\mathbf{H 2}$ potrdimo in zaključimo, da na odvisno 
spremenljivko Izbira študija - dvojna kariera vpliva Značilnosti študijskega programa dvojna kariera.

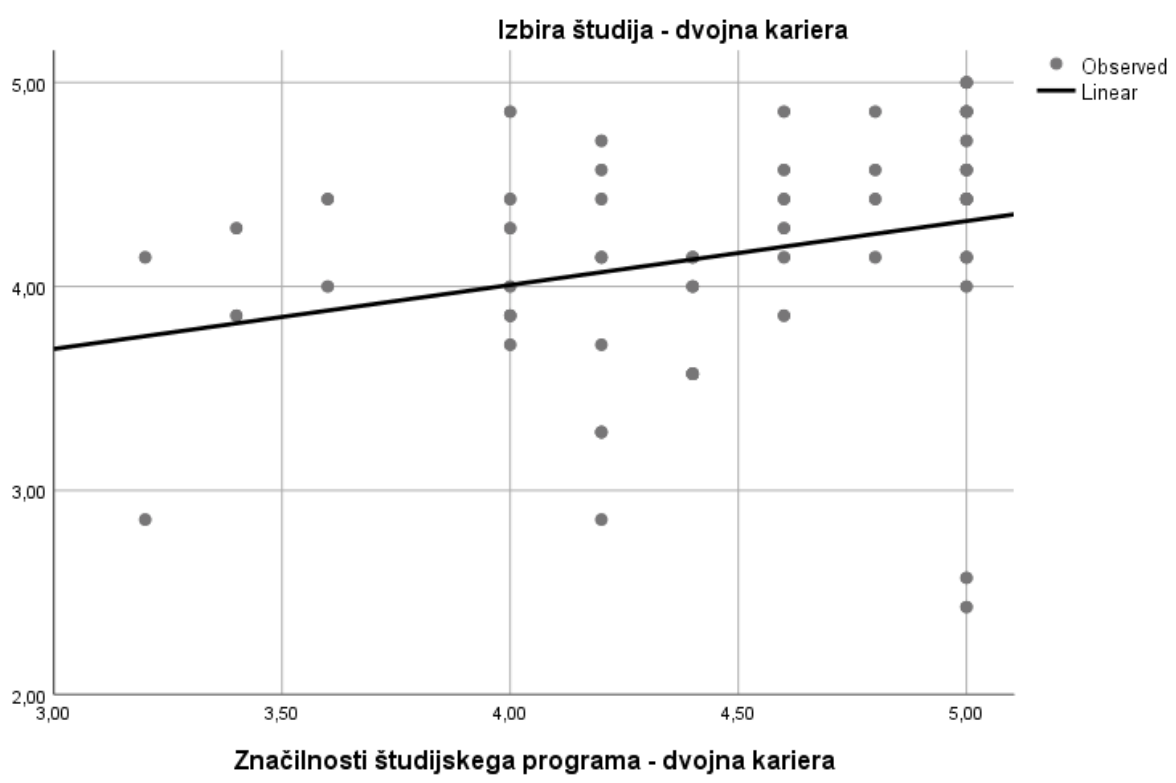

Slika 9. Linearna povezanost odvisne spremenljivke Izbira študija - dvojna kariera in neodvisne spremenljivke Značilnosti študijskega programa - dvojna kariera

Slika 9 prikazuje linearno povezanost med odvisno spremenljivko Izbira študija - dvojna kariera in neodvisno spremenljivko Značilnosti študijskega programa - dvojna kariera. Vidimo, da gre za pozitivno in linearno povezanost odvisne spremenljivke Izbira študija dvojna kariera in neodvisne spremenljivke Značilnosti študijskega programa - dvojna kariera.

Tretja hipoteza se glasi:

H3: Na športnikovo izbiro študija vplivajo tudi značilnosti športne aktivnosti (obseg treningov, tekmovanj, odsotnosti, fizična zahtevnost športa, oddaljenost bivanja od objektov za trening, nivo tekmovanja, motiviranost za šport, uspeh pri športu).

Za testiranje tretje hipoteze $\mathrm{H} 3$ preverimo povezanost med spremenljivkama Izbira študija dvojna kariera (izbira_st_1) in Značilnosti športne aktivnosti - dvojna kariera (sport_akt_l). Povezanost med tema dvema spremenljivkama preverimo $\mathrm{z}$ naslednjim populacijskim regresijskim modelom in hipotezo.

Populacijski regresijski model:

izbira_st_l $=\beta_{1}+\beta_{2} * s p o r t \_a k t \_1+u$

Hipoteza:

$H_{0}: \beta_{2}=0$ 
$H_{1}: \beta_{2} \neq 0$

Hipotezo H3 smo testirali z linearno regresijsko analizo (metoda Enter), kjer je odvisna spremenljivka Izbira študija - dvojna kariera (izbira_st_1) in neodvisna spremenljivka Značilnosti športne aktivnosti - dvojna kariera (sport_akt_l).

Tabela 7. Linearna regresija $-\mathrm{H} 1.3$

\begin{tabular}{|c|c|c|c|c|c|c|c|}
\hline \multicolumn{8}{|c|}{ Povzetek modela } \\
\hline \multirow{2}{*}{\multicolumn{2}{|c|}{$\begin{array}{ll}\text { Model } & \mathbf{R} \\
1 & 0,149^{\mathrm{a}}\end{array}$}} & \multirow{2}{*}{$\begin{array}{l}\mathbf{R}^{2} \\
0,022\end{array}$} & \multicolumn{2}{|c|}{ Prilagojeni $\mathbf{R}^{2}$} & \multicolumn{3}{|c|}{ Standardna napaka ocene } \\
\hline & & & 0,01 & & 0,58309 & & \\
\hline \multicolumn{8}{|c|}{ a. Neodvisne spremenljivke: Značilnosti športne aktivnosti - dvojna kariera } \\
\hline \multicolumn{8}{|c|}{ ANOVA $^{\mathrm{a}}$} \\
\hline \multicolumn{2}{|c|}{ Model } & Vsota kvadratov & sp & \multicolumn{2}{|c|}{ Povprečni kvadrat } & $\mathbf{F}$ & $\begin{array}{l}\text { p } \\
\text { vrednost }\end{array}$ \\
\hline \multirow[t]{2}{*}{1} & resija & 0,832 & 1 & 0,832 & & 2,446 &, $121^{\mathrm{b}}$ \\
\hline & stali & 36,719 & 108 & 0,340 & & & \\
\hline \multicolumn{2}{|c|}{ Skupaj } & 37,551 & 109 & & & & \\
\hline
\end{tabular}

a. Odvisna spremenljivka: Izbira študija - dvojna kariera

b. Neodvisne spremenljivke: Značilnosti športne aktivnosti - dvojna kariera

Koeficienti $^{\text {a }}$

Nestand.

koeficienti Stand. koeficienti

\begin{tabular}{|c|c|c|c|c|c|}
\hline Model & $\boldsymbol{\beta}$ & $\begin{array}{l}\text { St. } \\
\text { napaka }\end{array}$ & Beta & $\mathbf{t}$ & $\begin{array}{l}\text { p } \\
\text { vrednost }\end{array}$ \\
\hline 1 (Konstanta) & 3,555 & 0,380 & & 9,357 & 0,000 \\
\hline $\begin{array}{l}\text { Značilnosti športne aktivnosti - dvojna } \\
\text { kariera }\end{array}$ & 0,155 & 0,099 & 0,149 & 1,564 & 0,121 \\
\hline
\end{tabular}

a. Odvisna spremenljivka: Izbira študija - dvojna kariera

V tabeli 7 multipli korelacijski koeficient $R$ kaže jakost povezanosti med odvisno spremenljivko Izbira študija - dvojna kariera (izbira_st_1) in neodvisno spremenljivko Značilnosti športne aktivnosti - dvojna kariera (sport_akt_l). Multipli korelacijski koeficient $R$ znaša 0,149, kar kaže na neznatno povezanost. Multipli determinacijski koeficient pojasnjuje, da je 1,3\% celotne variance uspelo pojasniti z vplivom neodvisne spremenljivke, 
kar predstavlja 98,7\% nepojasnjenega vpliva. V Tabeli 7 je $p$-vrednost $0,121>0,05$ in pri 5 $\%$ tveganju trdimo, da je naš model ni dober. Na podlagi dobljenih rezultatov in vrednosti regresijskih koeficientov $\beta$ hipoteze $\mathbf{H 3}$ ne potrdimo in zaključimo, da na odvisno spremenljivko Izbira študija - dvojna kariera ne vpliva Značilnosti športne aktivnosti dvojna kariera.

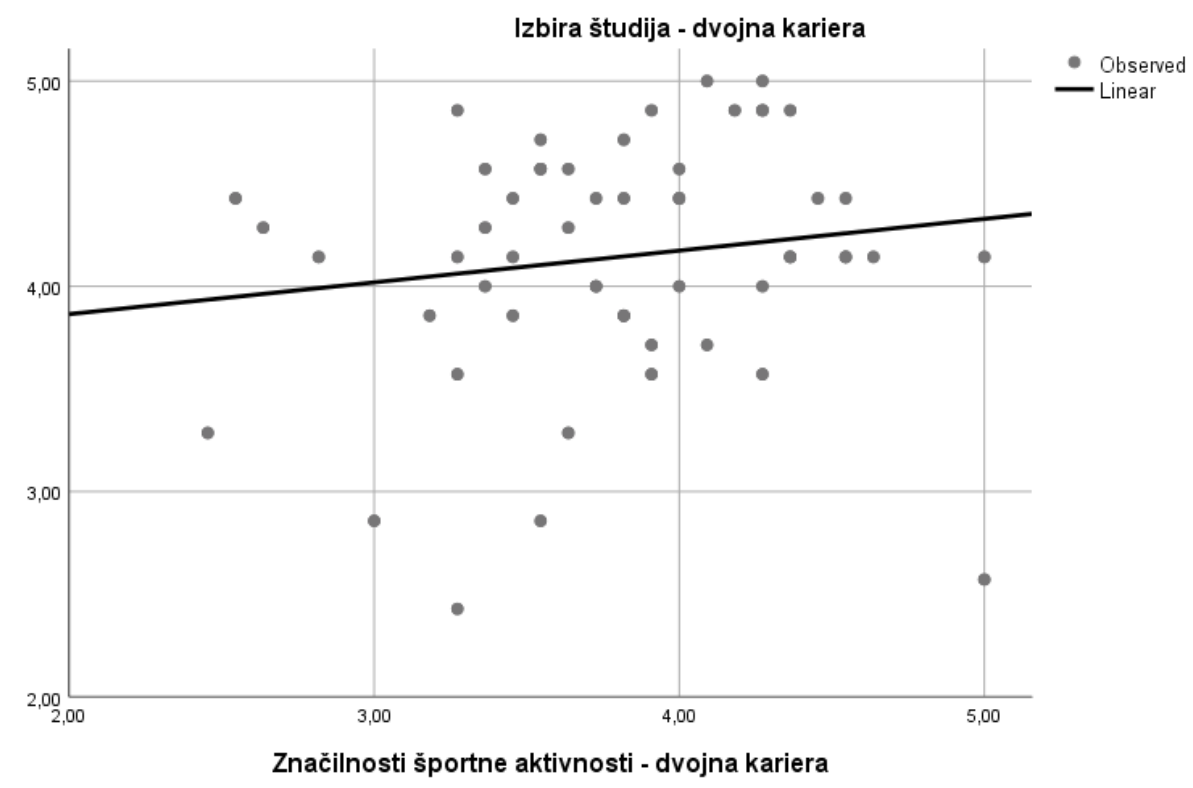

Slika 10. Linearna povezanost odvisne spremenljivke Izbira študija - dvojna kariera in neodvisne spremenljivke Značilnosti športne aktivnosti - dvojna kariera

Slika 10 prikazuje linearno povezanost med odvisno spremenljivko Izbira študija - dvojna kariera in neodvisno spremenljivko Značilnosti športne aktivnosti - dvojna kariera. Vidimo, da gre za pozitivno in linearno povezanost odvisne spremenljivke Izbira študija - dvojna kariera in neodvisne spremenljivke Značilnosti športne aktivnosti-dvojna kariera.

Raziskovalna hipoteza se glasi:

Na športnikovo izbiro študija vplivajo osebnostni dejavniki, značilnosti študijskega programa in značilnosti športne kariere.

Za testiranje raziskovalne hipoteze preverimo povezanost med spremenljivkami Izbira študija - dvojna kariera (izbira_st_1), Osebnostni dejavniki - dvojna kariera (oseb_dej_1), Značilnosti študijskega programa - dvojna kariera (znac_studij_1) in Značilnosti športne aktivnosti-dvojna kariera (sport_akt_1). Povezanost med temi spremenljivkami preverimo z naslednjim populacijskim regresijskim modelom in hipotezo.

Populacijski regresijski model:

$i z b i r a \_s t \_1=\beta_{1}+\beta_{2} * o s e b \_d e j \_1+\beta_{3} * z n a c \_s t u d i j \_1+\beta_{4} * s p o r t \_a k t \_1+u$ 


\section{Hipoteza:}

$H_{0}: \beta_{2}=0$

$$
\begin{aligned}
& \beta_{3}=0 \\
& \beta_{4}=0
\end{aligned}
$$

$H_{1}:$ Vsaj ena od domnev $v H_{0}$ ne velja

Raziskovalno hipotezo smo testirali z linearno regresijsko analizo (metoda Enter), kjer je odvisna spremenljivka Izbira študija - dvojna kariera (izbira_st_1) in neodvisne spremenljivke: Osebnostni dejavniki - dvojna kariera (oseb_dej_1), Značilnosti študijskega programa - dvojna kariera (znac_studij_l) in Značilnosti športne aktivnosti - dvojna kariera (sport_akt_l).

Tabela 8. Linearna regresija

\section{Povzetek modela}

\begin{tabular}{lllll} 
Model & $\mathbf{R}$ & $\mathbf{R}^{2}$ & Prilagojeni $\mathbf{R}^{2}$ & Standardna napaka ocene \\
\hline 1 & $0,350^{\mathrm{a}}$ & 0,122 & 0,098 & 0,55757
\end{tabular}

a. Neodvisne spremenljivke: Značilnosti športne aktivnosti - dvojna kariera, Osebnostni dejavniki - dvojna kariera, Značilnosti študijskega programa - dvojna kariera

ANOVA $^{a}$

\begin{tabular}{lllllll} 
Model & & $\begin{array}{l}\text { Vsota } \\
\text { kvadratov }\end{array}$ & sp & $\begin{array}{l}\text { Povprečni } \\
\text { kvadrat }\end{array}$ & F & p-vrednost \\
\hline 1 & Regresija & 4,598 & 3 & 1,533 & 4,930 & $0,003^{\mathrm{b}}$ \\
& Preostali & 32,953 & 106 & 0,311 & & \\
& & & & & \\
& Skupaj & 37,551 & 109 & & & \\
\end{tabular}

a. Odvisna spremenljivka: Izbira študija - dvojna kariera

b. Neodvisne spremenljivke: Značilnosti športne aktivnosti - dvojna kariera, Osebnostni dejavniki - dvojna kariera, Značilnosti študijskega programa - dvojna kariera

Koeficienti $^{\text {a }}$ 


\begin{tabular}{|c|c|c|c|c|c|c|}
\hline \multirow[b]{2}{*}{ Model } & & \multicolumn{2}{|c|}{ Nestand. koeficienti } & \multicolumn{2}{|l|}{$\begin{array}{l}\text { Stand. } \\
\text { koeficienti }\end{array}$} & \multirow[b]{2}{*}{ p-vrednost } \\
\hline & & $\boldsymbol{\beta}$ & $\begin{array}{l}\text { St. } \\
\text { napaka }\end{array}$ & Beta & $\mathbf{t}$ & \\
\hline \multirow[t]{4}{*}{1} & (Konstanta) & 1,919 & 0,594 & & 3,230 & 0,002 \\
\hline & $\begin{array}{l}\text { Osebnostni dejavniki - dvojna } \\
\text { kariera }\end{array}$ & 0,326 & 0,136 & 0,242 & 2,399 & 0,018 \\
\hline & $\begin{array}{l}\text { Značilnosti študijskega } \\
\text { programa - dvojna kariera }\end{array}$ & 0,279 & 0,120 & 0,243 & 2,331 & 0,022 \\
\hline & $\begin{array}{l}\text { Značilnosti športne aktivnosti - } \\
\text { dvojna kariera }\end{array}$ & $-0,075$ & 0,115 & $-0,072$ & $-0,647$ & 0,519 \\
\hline
\end{tabular}

a. Odvisna spremenljivka: Izbira študija - dvojna kariera

V tabeli 8 multipli korelacijski koeficient $R$ kaže jakost povezanosti med odvisno spremenljivko Izbira študija - dvojna kariera in neodvisnimi spremenljivkami Osebnostni dejavniki - dvojna kariera, Značilnosti športne aktivnosti - dvojna kariera in Značilnosti študijskega programa - dvojna kariera. Multipli korelacijski koeficient $R$ znaša 0,350 , kar kaže na nizko povezanost. Multipli determinacijski koeficient pojasnjuje, da je 9,8 \% celotne variance uspelo pojasniti z vplivom neodvisnih spremenljivk, kar predstavlja 90,2 \% nepojasnjenega vpliva. $\mathrm{V}$ Tabeli ANOVA je $p$-vrednost $0,003<0,05$ in lahko pri $5 \%$ tveganju trdimo, da je naš model dober. Na podlagi dobljenih rezultatov in vrednosti regresijskih koeficientov $\beta$ lahko raziskovalno hipotezo delno potrdimo in zaključimo, da na odvisno spremenljivko Izbira študija - dvojna kariera vplivata spremenljivki Osebnostni dejavniki - dvojna kariera in Značilnosti športne kariere - dvojna kariera. Na odvisno spremenljivko Izbira študija - dvojna pa ne vpliva spremenljivka Značilnosti študijskega programa-dvojna kariera.

V tabeli 9 predstavimo multivariantne analize povezav med proučevanimi spremenljivkami. Predstavljene so Pearsonove korelacije med spremenljivkami Osebnostni dejavniki - dvojna kariera, Izbira študija - dvojna kariera, Značilnosti študijskega programa - dvojna kariera in Značilnosti športne aktivnosti - dvojna kariera. 


\begin{tabular}{|c|c|c|c|c|c|}
\hline & & $\begin{array}{l}\text { Izbira študija - } \\
\text { dvojna kariera }\end{array}$ & $\begin{array}{l}\text { Osebnostni } \\
\text { dejavniki - } \\
\text { dvojna kariera }\end{array}$ & $\begin{array}{l}\text { Značilnosti } \\
\text { študijskega } \\
\text { programa - } \\
\text { dvojna kariera }\end{array}$ & $\begin{array}{l}\text { Značilnosti } \\
\text { športne } \\
\text { aktivnosti - } \\
\text { dvojna kariera }\end{array}$ \\
\hline \multirow[t]{3}{*}{$\begin{array}{l}\text { Izbira študija - } \\
\text { dvojna kariera }\end{array}$} & $\begin{array}{l}\text { Pearsonova } \\
\text { korelacija }\end{array}$ & 1 & $0,276^{* * *}$ & $\mathbf{0 , 2 7 3}{ }^{* *}$ & 0,149 \\
\hline & $\mathrm{p}$ - vrednost & & 0,003 & 0,004 & 0,121 \\
\hline & $\mathrm{N}$ & 110 & 110 & 110 & 110 \\
\hline \multirow[t]{3}{*}{$\begin{array}{l}\text { Osebnostni dejavniki } \\
\text { - dvojna kariera }\end{array}$} & $\begin{array}{l}\text { Pearsonova } \\
\text { korelacija } \\
\end{array}$ & & 1 & $0,267^{* *}$ & $0,427^{* *}$ \\
\hline & $\mathrm{p}-$ vrednost & & & 0,005 & 0,000 \\
\hline & $\mathrm{N}$ & & 110 & 110 & 110 \\
\hline \multirow{3}{*}{$\begin{array}{l}\text { Značilnosti } \\
\text { študijskega } \\
\text { programa - dvojna } \\
\text { kariera }\end{array}$} & $\begin{array}{l}\text { Pearsonova } \\
\text { korelacija }\end{array}$ & & & 1 & $\mathbf{0 , 4 8 3}^{* * *}$ \\
\hline & $\mathrm{p}$ - vrednost & & & & 0,000 \\
\hline & $\mathrm{N}$ & & & 110 & 110 \\
\hline \multirow{3}{*}{$\begin{array}{l}\text { Značilnosti športne } \\
\text { aktivnosti - dvojna } \\
\text { kariera }\end{array}$} & $\begin{array}{l}\text { Pearsonova } \\
\text { korelacija }\end{array}$ & & & & 1 \\
\hline & $\mathrm{p}$ - vrednost & & & & \\
\hline & $\mathrm{N}$ & & & & 110 \\
\hline
\end{tabular}

Tabela 9 prikazuje rezultate korelacijske matrike za spremenljivke Izbira študija - dvojna, Osebnostni dejavniki - dvojna kariera, Značilnosti študijskega programa - dvojna kariera in Značilnosti športne aktivnosti - dvojna kariera. Rezultati korelacijske matrike izbire študija dvojne kariere kažejo, da ima na osebnostne dejavnike dvojne kariere nizek vpliv (linearna, pozitivna in nizka povezanost). Vpliv na izbiro študija - dvojne kariere ima tudi značilnosti študijskega programa (linearna, pozitivna in nizka povezanost). Pozitiven vpliv na osebnostne dejavnike dvojne kariere ima tudi značilnosti študijskega programa (linearna, pozitivna in nizka povezanost). Osebnostni dejavniki dvojne kariere vplivajo na značilnost športne aktivnosti (linearna, pozitivno in srednja povezanost). Značilnosti študijskega programa vplivajo na značilnost športne aktivnosti (linearna, pozitivna in srednja povezanost).

Iz korelacijske matrike (tabela 9) je razvidno, da so neodvisne spremenljivke Osebnostni dejavniki - dvojna kariera, Značilnosti študijskega programa - dvojna kariera in Značilnosti športne aktivnosti - dvojna kariera povezane z odvisno spremenljivko Izbira študija - dvojna kariera. Neodvisne spremenljivke Osebnostni dejavniki - dvojna kariera in Značilnosti študijskega programa - dvojna kariera ter Osebnostni dejavniki - dvojna kariera in Značilnosti športne aktivnosti - dvojna kariera ter Značilnosti študijskega programa - dvojna kariera in Značilnosti športne aktivnosti - dvojna kariera pa so tudi povezane med sabo. 


\section{Zaključek}

Namen raziskave je bilo ugotoviti kateri dejavniki vplivajo na uspešno usklajevanje dvojne kariere. Izvedli smo spletno anketo med 112 slovenskimi športniki. Anketirani so bili amaterski vrhunski športniki, ki se ali so se ukvarjali z usklajevanjem športne in akademske kariere.

$\mathrm{Na}$ podlagi raziskovalnega vprašanja »Na športnikovo izbiro študija vplivajo osebnostni dejavniki, značilnosti študijskega programa in značilnosti športne kariere. " smo ugotovili, da na športnikovo izbiro študija vplivajo osebnostni dejavniki (sposobnosti, interesi, predhodni šolski uspeh, motivacija). Na športnikovo izbiro študija vplivajo značilnosti študijskega programa (zahtevnost, obseg študijskih obremenitev, možne prilagoditve) in na športnikovo izbiro študija ne vplivajo značilnosti športne aktivnosti (obseg treningov, tekmovanj, odsotnosti, fizična zahtevnost športa, oddaljenost bivanja od objektov za trening, nivo tekmovanja, motiviranost za šport, uspeh pri športu).

S korelacijsko matriko izbire študija - dvojne kariere smo ugotovili, da ima izbira študija dvojne kariere na osebnostne dejavnike nizek vpliv (linearna, pozitivna in nizka povezanost). Vpliv na izbiro dvojne kariere imajo tudi značilnosti študijskega programa (linearna, pozitivna in nizka povezanost). Pozitiven vpliv na osebnostne dejavnike pri dvojni karieri imajo tudi značilnosti študijskega programa (linearna, pozitivna in nizka povezanost). Osebnostni dejavniki za izbiro dvojne kariere vplivajo na značilnosti športne aktivnosti (linearna, pozitivno in srednja povezanost). Značilnosti študijskega programa vplivajo na značilnosti športne aktivnosti (linearna, pozitivna in srednja povezanost).

Raziskovalno vprašanje smo delno potrdili. To pomeni, da smo delno potrdili povezavo med športnikovo uspešnostjo pri študiju, osebnostnimi dejavniki, značilnostjo študijskega programa in značilnostmi športne aktivnosti. Hipotezo H1 smo potrdili, saj obstaja povezava med izbiro študija in osebnostnimi dejavniki. Hipotezo H2 smo tudi potrdili, saj obstaja povezava med izbiro študija in značilnostjo študijskega programa. Hipoteze H3 nismo potrdili, saj ne obstaja povezava med izbiro študija in značilnosti športne aktivnosti.

Iz raziskave smo ugotovili, da so bili anketiranci zadovoljni z dejavniki izbire študija. Najbolj so bili zadovoljni $\mathrm{z}$ razumevanjem izobraževalne organizacije za športno udejstvovanje in podporo pri izobraževanju. $\mathrm{K}$ uspešnemu usklajevanju dvojne kariere so pripomogli tudi osebnostni dejavniki, kot so dobro organiziran čas, dobre delovne navade, vztrajnost in interes za študij. Na značilnosti študijskega programa za uspešno usklajevanje dvojne kariere so najbolj vplivale možnosti prilagoditve študijskih obveznosti, fleksibilnost višje/visokošolskega zavoda ter zahtevnost študijskega programa.

Višje oziroma visokošolskim zavodom priporočam, naj upoštevajo dejavnike za prilagajanje študija športnikom, saj se bo s tem povečala izobrazba športnikov. Posledično se bo zmanjšalo breme usklajevanja študija in športa, saj je pomembno, da športniki med vrhunsko kariero končajo študij, saj bodo tako športniki po končani športni karieri lažje zaposljivi. 


\section{Reference}

1. Aquilina, D. in Henry, I. (2010). Elite athletes and university education in Europe: A review of policy and practice in higher education in the European UnionMember States. International Journal of Sport policy, 1(1), 24-47.

2. Bednarik, J., Ferenčak, M. in Turšič, N. (2002). Nekatere socialno-ekonomske značilnosti slovenskih športnikov in športnic. Ljubljana: Fakulteta za šport.

3. Bon, M. (2011). A Sports Career and Education: Characteristics of participants in specialised handball classes. Kinesiologia Slovenica, 17( 1), 15-27.

4. Brečko, D. (2006). Načrtovanje kariere kot dialog med organizacijo in posameznikom. Ljubljana: Planet GV.

5. Brewer, B. W., Van Raalte, J. L. in Petitpas, A. J. (2000). Self-identity in sport career transitions. V D. Lavallee in P. Wylleman (ur.), Career transitions in sport: International perspective. Morgantown: Fitness Information Technology.

6. Capranica, L., Foerster, J., Keldorf, O., Leseur, V., Vandewalle, P., Duopona Tpic, M., Abelkalns, I., Keskitalo, R, Kozsla, T., Figueiredo, A. in Guidotti, F. (2015). The European athlete as student network (»EAS«). Prioritising dual career of European student - athletes. Kinesiologia Slovenica, $21(2)$, str $5-10$.

7. Corrado, L., Tessitore, A., Capranica, L., Rauter, S. in Doupona Topic, M. (2012). Motivation for a dual career: Italian and Slovenian student-athletes. Kinesiologia Slovenica, 18(3), 47-56.

8. Cecić Erpič, S. (2002a). Konec športne kariere: razvojno-psihološki in športno-psihološki vidiki. Ljubljana: Fakulteta za šport.

9. Clow, C. T. (2000). Student- athl etes' perceived value of education: Effects of a career exploration interwention. Doctor Dissertation, Auburn: Auburn Unniversity.

10. Fuchs X., Wagner, H., Hannola, H., Niemisalo, N., Pehme, A., Puhke, R., Marinsek, M., Stermecki, A., Svetec, D., Brown, A., Capranica, L. in Guidotti, F. (2016). European studentathletes' perceptions on dual career outcomes and services. Kinesiologia Slovenica, 22 (2), 31-48.

11. Gaston-Gayles, J. L. (2005). Academic exploitation. The adverse impact of college athletics on the educational success of minority student-athletes. Seattle Journal for Social Justice, 10(1), 509583.

12. Guidotti, F., Lupo, C., Cortis, C., Baldassarre, A. in Capranica, L. (2014). Italian teachers' perceptions regarding talented atypical students: a preliminary study. Kinesiologia Slovenica, 20 (3), $36-46$.

13. Jameson, M. (2007). Stereothype threat impacts college athletes' academic performance. Connecticut: Wesleyan university.

14. Jurak, G., Bednarik, J., Plestenjak, G., Kolar, E., Jagodic, T. in Kovač, M. (2007). Sponzorske možnosti slovenskega športa. V Jurak G. Nekateri kazalniki

15. Jurak, G., Kovač, M. in Strel, J. (2003). Učne možnosti perspektivnih športnikov. V Jurak G., Kovač M. in Strel J., Śportno nadarjeni otroci in dijaki v šoli: analiza nekaterih organizacijskih modelov in priprava strokovnih podlag za nekatere posebne organizacijske oblike v vzgoji in izobraževanju. Ljubljana, Fakulteta za šport.

16. Kovač, M., Jurak, G. in Strel, J. (2004). Možnosti enakopravnega izobraževanja za dijake športnike. Šport, 52(4), 13-15.

17. Kovač, M., Kolar, E., Bednarik, J. in Doupona Topič, M. (2005). Vpliv vrhunskih rezultatov na razvoj športa, nacionalno identifikacijo in prepoznavnost Slovenije v Evropi in svetu. V M. Kovač 
in G. Starc (ur.), Šport in nacionalna identifikacija Slovencev. Ljubljana: Univerza v Ljubljani, Fakulteta za šport, Inštitut za kineziologinjo.

18. Mikolavčič, M. (2010). Poklicna kariera vrhunskega športnika po končani športni poti. (Diplomsko delo). Ljubljana: Fakulteta za šport.

19. Ogilvie, B. C. in Taylor, J. (1993). Career termination issues among elite athletes. Handbook of research on sport psychology (761-779). New York: Macmillan publishing company.

20. Pettaway Willis, K. J. (2005). Female basketball student- athletes motivation: Analyzing academic standing and ethnicity at Atlantic coast conference institutions. Doctoral dissertation, Florida: The Florida state University.

21. Simons, H. D., Van Rheenen, D. in Covington, M. V. (1999). Academic motivation and the student athlete. Journal of College Student Development, 40(2), 151-162.

22. Sivec, J. (2005). Povezanost socialnih dejavnikov z uspešnostjo slovenskih vrhunskih športnikov in športnic. (Magistrska naloga). Ljubljana: Univerza v Ljubljani, Fakulteta za šport.

Mojca Braz mag. je je doktorska študenta na Fakulteti za komercialne in poslovne vede v Celju. Zaposlena je kot direktorica projektivnega biroja Eldata d.o.o., opravlja pa delo v nadzornem svetu Družbe Arboretum.

Doc. dr. Mateja Gorenc je diplomirana inženirka matematike, magistrica financ in računovodstva, magistrica poslovnih ved ter doktorica poslovnih ved. Je certificirana preiskovalka prevar na področju financ in računovodstva. Zaposlena je v sektorju informacijskih tehnologij, v službi za programiranje in upravljanje $\mathrm{z}$ aplikacijami. Je predavateljica Poslovne matematike in Statistike na Mednarodni fakulteti za družbene in poslovne študije ter predavateljica za predmeta Matematika in Statistika za preiskovalce prevar na Visoki šoli za računovodstvo in finance.

\section{Abstract: \\ Successful Coordination of Top Athletes' Dual Careers}

Research Question: What factors influence a successful coordination of top athletes' dual careers? Purpose: The purpose of successfully coordinating the dual careers of top athletes is to obtain education during a sports career. The acquired education helps to increase the employability of the athlete after his / her sports career.

Method: We used a quantitative method of research, descriptive analysis, linear and multiple analysis. The statistical analysis was performed with the help of the SPSS statistical programme.

Results: The research found that a successful coordination of a dual career is influenced by personality factors and characteristics of the study programme.

Organization: Colleges and higher education institutions should be aware that they have to adapt the studies to the athletes, as this will increase the education level of the latter.

Society: Athletes will be more employable after completing their sports careers.

Originality: Based on the data and findings obtained, suggestions have been made to improve the dual careers of athletes in Slovenia.

Limitations / Further Research: The study was limited to only interviewing Slovenian top athletes. 
Izzivi prihodnosti / Challenges of the Future,

Avgust / August 2020, leto / year 5, številka / number 3, str. / pp. 151-173.

Key words: dual career of athletes, career in sports, student athlete, decision to study, academic success, student status, distance learning, evaluation of study adjustments to athletes.

Copyright (c) Mojca BRAZ, Mateja GORENC

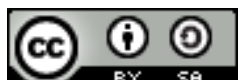

Creative Commons License

This work is licensed under a Creative Commons Attribution-ShareAlike 4.0 International License 